\title{
Peran Lembaga Swadaya Masyarakat dalam Penetapan Taman Nasional Lore Lindu: Studi Yayasan Tanah Merdeka dalam Memperjuangkan Hak Masyarakat Katu
}

\author{
Mohamad Bustam ${ }^{1}$
}

\begin{abstract}
Abstrak
Lembaga swadaya masyarakat ini berupaya memperjuangkan hak komunitas lokal dalam isu kebijakan penetapan kawasan taman nasional. Tujuan penulisan ini mengidentifikasi peran dan strategi Yayasan Tanah Merdeka (YTM) dalam memperjuangkan hak komunitas Orang Katu atas penetapan Kawasan Taman Nasional Lore Lindu Sulawesi Tengah. Data dikumpulkan menggunakan metode kualitatif dan disajikan secara deskriptif. Studi mengungkapkan YTM memainkan peran strategis dalam menciptakan hegemoni tandingan atas kebijakan penetapan kawasan Taman nasional Lore Lindu di wilayah komunitas Orang Katu. Hal ini dilakukan dengan membentuk kesadaran kolektif, melibatkan komunitas dalam gerakan akar rumput, mengembangkan strategi perjuangan melalui penyusunan dokumen pengelolaan sumber daya alam berbasis pengetahuan lokal serta, penggunaan terminologi masyarakat adat sebagai instrumen perjuangan yang dihubungkan dengan wacana hak global sehingga menjadi kekuatan yang konstitutif dalam arena politik pengelolaan sumber daya alam pada tingkat lokal.
\end{abstract}

Kata kunci: Lembaga swadaya masyarakat, gerakan masyarakat adat, kebijakan taman nasional

\begin{abstract}
This non-governmental organization seeks to fight for the rights of local communities in the policy issue of setting the national park area. This paper aims to identify the role of Yayasan Tanah Merdeka (YTM) in the struggling rights of the Orang Katu community for the establishment of the Lore Lindu National Park Area. Data is collected using qualitative methods and presented descriptively. The study revealed that YTM played a strategic role in creating counter-hegemony over the policy of establishing Lore Lindu National Park in the Katu community area. Conducted by establishing collective awareness, involving communities in grassroots movements, the strategy is developed through the preparation of documents on the management of natural resources based on local knowledge as well as, the use of indigenous terminology that is connected with global rights discourse to become a constitutive force in the political arena of natural resource management at the local level.
\end{abstract}

Keywords: non-government organization, indigenous movement, national park policy

\section{Pendahuluan}

Sumber daya hutan merupakan sumber daya yang memiliki tingkat keanekaragaman hayati yang tinggi, wilayah ini biasanya dihuni oleh masyarakat adat terutama di wilayah Amerika Latin, Afrika dan Asia Tenggara (Pretty, 2009). Secara umum masyarakat adat adalah keturunan sekelompok individu yang telah mendiami suatu kawasan tertentu sebelum wilayah itu ditaklukkan atau dijajah sekelompok masyarakat lain (Kingsbury, 1998). Di Indonesia masyarakat adat merupakan masyarakat yang mempunyai asal-usul dari suatu geografis tertentu serta memiliki sistem nilai, ideologi, ekonomi, politik, budaya dan pengelolaan tanah yang khas (Moniaga, 2010), Meskipun demikian, sumber daya alam yang dimiliki sering menjadi sasaran dari kebijakan maupun proyek pengembangan sumber daya alam oleh negara (Lennox, 2012). Akibatnya terjadi penyingkiran, perampasan dan pengusiran masyarakat adat atas ruang hidupnya (Kelly, 2011) menjadi konsekuensi logis dalam pelaksanaan kebijakan pembangunan, khususnya kebijakan kawasan konservasi atau penetapan Taman Nasional. Hal ini merupakan bentuk politik kehutanan yang sedang dipraktikkan oleh negara (Vandergeest \& Peluso, 1995). Alih-alih mengembangkan ekonomi komunitas lokal, negara melalui kekuasaannya melakukan diskriminasi terhadap komunitas lokal atas sumber daya alam yang dimiliki secara turun temurun.

\footnotetext{
${ }^{1}$ Departemen Pembangunan Sosial dan Kesejahteraan, Universitas Gadjah Mada (email korespondensi: mohamad.bustam@mail.ugm.ac.id)
} 
Sehingga fenomena ini berujung pada konflik pemanfaatan sumber daya alam antara negara dan komunitas lokal.

Konflik yang terjadi sebenarnya berakar pada pandangan negara yang memaksakan penduduk lokal melalui proyek-proyek kesejahteraan dan ketertiban masyarakat, serta perlindungan kawasan hutan. Teknik dasar dari proyek ini adalah pemindahan penduduk dari kawasan hutan serta penetapan tapal batas "hutan politik" sesuai klaim Negara (Li, 2012:115). Hal ini yang terjadi pada Penetapan kawasan Taman Nasional Lore Lindu (TNLL) pada tahun 1993, memperlihatkan sebuah proses hegemoni negara atas komunitas lokal yang hidup di sekitar hutan, melalui pelaksanaan undangundang pelestarian sumber daya alam tahun 1990 tentang pelarangan aktivitas pertanian dan hunian masyarakat dalam kawasan hutan. Ribot dan Peluso (2006) menjelaskan ini sebagai kemampuan untuk mendapat manfaat yang dipengaruhi oleh serangkaian kuasa. Tidakjarang hak kelola komunitas dibatasi karena dianggap merusak lingkungan, bahkan disematkan dengan stigma sebagai pencuri hasil hutan negara, serta ancaman pemindahan melalui proyek involuntary resettlement (Sangadji, 2002; D’Andrea, 2013). Kondisi ini didasarkan pada anggapan negara terhadap komunitas lokal sebagai ancaman ekologis, peladang tidak efisien, perambah liar atau stigmatisasi buruk lainnya (Cahyono, 2013). Sebagian dari mereka meninggalkan perkampungan untuk sekedar mengikuti keinginan pemerintah (Rangi, 2013:40-44). Namun hal ini sangat berbeda dengan Komunitas Orang Katu yang terpaksa harus keluar masuk hutan untuk menghindari petugas kehutanan karena menolak dipindahkan. Orang Katu menganggap tanah tempat mereka hidup merupakan tanah warisan leluhur yang harus dijaga, meskipun kebingungan dalam menghadapi tekanan dan ancaman dari otoritas TNLL.

Kondisi komunitas lokal ini oleh Scott (1985) disebut dalam posisi "powerless", tidak memiliki keberanian politik untuk melakukan perlawanan. Oleh karena itu dibutuhkan aktor civil society atau yang dikenal sebagai Lembaga Swadaya Masyarakat (LSM) yang bertujuan mendorong penguatan komunitas lokal yang tersingkir, tertindas dan teralienasi dalam kebijakan pembangunan (Clark, 1995). Meskipun demikian, kemampuan LSM untuk mempromosikan demokrasi bergantung pada proses bagaimana LSM mendapatkan kepercayaan publik atau kekuatan dari akar rumput. Jika LSM menjadi agen penguatan demokratisasi masyarakat dalam proses pembangunan, maka tidak cukup hanya melihat pada misi fungsional belaka untuk melegitimasi kerja-kerja mereka di lapangan (Lang, 2013). LSM harus memfokuskan pada pelibatan masyarakat yang lebih luas menuju advokasi publik, dengan menggunakan strategi inovatif untuk berkomunikasi dalam memperkuat posisi masyarakat (Choudry \& Kapoor, 2013).

Salah satu bentuk pengabaian hakhak komunitas lokal dalam penetapan kawasan Taman Nasional Lore Lindu yakni pengambilalihan secara paksa lahan masyarakat melalui Surat Keputusan Menteri Kehutanan Nomor 593/Kpts-II/93. Dengan menetapkan tapal batas kawasan taman nasional sebagai klaim negara pada hutan yang dianggap memiliki kekayaan biodiversity. Secara bersamaan praktek tersebut telah membatasi akses masyarakat terhadap hutan. Petugas kehutanan menekan penduduk untuk tidak melakukan perburuan dan melarang memanfaatkan hasil hutan baik kayu maupun non kayu. Hal ini sesuai amanat undang-undang pelestarian alam tahun 1990 tentang pelarangan kegiatan pertanian dan hunian di dalam kawasan taman nasional. Pengabaian komunitas lokal atas sumber daya alam dalam kebijakan penetapan TNLL, menggambarkan posisi tawar masyarakat yang sangatrendah di hadapan negara. Dalam studi ini khususnya komunitas Orang Katu yang beberapa kali dipindahkan dari tanah leluhurnya. Hal ini mendorong sekelompok aktivis lokal yang tergabung dalam Yayasan Tanah Merdeka (YTM) menawarkan bantuan pada komunitas Orang Katu untuk memperjuangkan hak atas sumber daya alam yang dimiliki secara turun temurun. Keterlibatan YTM dalam memperjuangkan hak Komunitas Orang Katu atas sumber daya alam, merupakan proses mewujudkan partisipasi masyarakat dalam kebijakan pembangunan. Meskipun demikian, fenomena kehadiran LSM dalam masyarakat tidak terlepas dari kepentingan (Giri \& Ufford, 2002). Munculnya isu menjual permasalahan masyarakat yang dibungkus dengan retorika populis untuk mendapatkan aliran dana dari pihak donor (Petras dan Veltmeyer, 2002:238), merupakan bentuk respon publik terhadap agen alternatif 
Mohamad Bustam - Peran Lembaga Swadaya Masyarakat dalam Penetapan Taman Nasional Lore Lindu: Studi Yayasan Tanah Merdeka dalam Memperjuangkan Hak Masyarakat Katu

pembangunan ini. Oleh karena itu, Wallace \& Porter (2013) dalam (Banks et.al, 2015:711) menyatakan pentingnya melihat sejauh mana LSM terlibat dan terhubung dengan kelompok yang mereka klaim untuk diwakili, serta seperti apa kerja-kerja mereka diarahkan. Sehingga itu menarik untuk diteliti dengan mengajukan pertanyaan bagaimana peran dan strategi YTM dalam memperjuangkan hak Komunitas Orang Katu atas sumber daya alamnya.

\section{Kerangka Teori}

Peran Lembaga Swadaya Masyarakat

Lembaga swadaya masyarakat dalam perkembangannya di elaborasi dalam beberapa generasi. Pertama, adalah LSM yang bergerak dalam bantuan kemanusiaan terutama berkaitan dengan bencana alam, Kedua, LSM yang bergerak dalam pemberdayaan dan pembangunan dalam tingkat lokal, serta Ketiga, LSM yang bekerja dalam isu-isu keberlanjutan pembangunan termasuk pada isu-isu advokasi kebijakan (Korten, 1987). Berangkat dari perkembangan LSM generasi terakhir, Eldridge (1988) menyebutnya sebagai bentuk LSM mobilisasi, yang memainkan peran sangat penting dalam gerakan demokrasi melalui pemberdayaan masyarakat dengan melakukan kerja pendampingan, pembelaan dan penyadaran. Model LSM ini pada dasarnya memiliki misi penguatan masyarakat di luar negara maupun swasta. Dengan kata lain menjadi agen yang menjembatani masyarakat dan negara atau menjadi penyeimbang kekuatan negara dalam penentuan kebijakan. Dengan demikian fenomena kehadiran LSM dalam memperjuangkan hak masyarakat atas sumber daya alam, merupakan respon agen masyarakat sipil atas kebijakan pemanfaatan sumber daya alam yang membatasi hak kelola masyarakat atas ruang hidupnya. Pada titik inilah LSM Mengambil peran strategis dalam menciptakan gerakan masyarakat menuju pembangunan yang inklusif dan berkeadilan melalui serangkaian penyadaran dan pendidikan politik bagi masyarakat (Fakih, 1996).

\section{Hegemoni dan Counter-Hegemoni}

Kebijakan alih fungsi kawasan hutan menjadi taman nasional merupakan produk kebijakan negara yang membatasi hak kelola komunitas yang telah lama mendiami kawasan tertentu. Sebagaimana Vandergeest dan Peluso (1995) menyatakan sebagai proses teritorialisasi untuk mencapai berbagai tujuan. Fenomena penetapan kawasan taman nasional merupakan bentuk politik kehutanan yang diklasifikasikan sebagai hutan permanen dan dikelola oleh lembaga pemerintah yang profesional (Peluso dan Vandergeest, 2011), oleh karena itu ketika suatu wilayah telah ditentukan sebagai hutan negara, seperangkat imajinasi geografis dan politik tertentu digunakan untuk membenarkan kekerasan negara dan menghasilkan kontrol atas suatu teritorial, sebagai strategi dan praktik yang telah dikalkulasi sedemikian rupa untuk mendidik keinginan dan membentuk kebiasaan dan kepercayaan individu maupun kelompok dalam masyarakat (Li, 2007).

Penjelasan di atas disebut Gramsci sebagai proses hegemoni yang sedang berlangsung oleh kelas tertentu terhadap kelas lainnya, dengan kata lain negara dan masyarakat dalam hubungan hegemonik. Hegemoni merupakan kemenangan yang dicapai melalui mekanisme konsensus, ketimbang melalui penindasan untuk mendorong individu atau kelompok tertentu agar menilai dan menjalankan problematika sosial yang ditentukan (Patria \& Arief, 1999:123128). Dengan demikian legitimasi kelompok berkuasa tidak ditentang, karena ideologi, nilai dan norma politiknya sudah diterima oleh kelompok subordinat. (Sugiono, 1999; Morton, 2007). Sehingga dipahami hegemoni bukanlah sesuatu yang dipaksakan, melainkan dilakukan dalam aksi-aksi politis dan kultural melalui kepemimpinan dan ideologi guna mendapatkan konsensus (Femia, 1975; Simon, 1999; Patria \& Arief, 1999; Sugiono, 1999).

Hubungan hegemonik yang terus menerus dimenangkan oleh kelas penguasa, secara simultan menciptakan ketidakseimbangan dalam struktur negara, sehingga memungkinkan munculnya gerakan perlawanan terhadap wacana dominan. Hal ini dilakukan dengan menciptakan konsepsi hegemoni mereka sendiri tentang kepentingan umum yang mampu mengantarkan pada politik transformatif (Carroll \& Ratner, 2010), melalui perangkat intelektual yang menyebarkan ideologi, sebagaimana Gramsci menyatakan ideologi berfungsi mengatur dan memberikan tempat bagi manusia untuk bergerak mendapatkan kesadaran posisi dan perjuangannya (Simon, 1999:83). Gramsci menyebutnya sebagai peran intelektual organik di mana satu atau lebih strata intelektual yang memberikan homogenitas dan kesadaran tidak 
hanya pada aspek ekonomi tetapi juga di bidang sosial dan politik (Gottlieb, 1989). Dari kelompok intelektual inilah progresifitas tumbuh dengan cepat. Karena didukung kemampuan untuk mengorganisir massa melalui pembentukan kesadaran dan menciptakan aksi kolektif sebagai kekuatan politik melawan hegemoni negara.

Pada posisi ini LSM disebut sebagai intelektual organik yang menciptakan kesadaran ideologis terhadap individu maupun kelompok masyarakat atas posisi mereka di hadapan negara. Uraian tersebut, sangat relevan dengan pembentukan kontra hegemoni dari kelas-kelas subordinat menentang hegemoni dominan dan berusaha menggantikannya dengan membentuk hegemoni alternatif (Hunt, 1990). Dalam Pengertian inilah LSM menampilkan diri sebagai kekuatan kontra hegemoni (Mc Sweeney, 2014; Girei, 2015). Implikasi dari pemahaman ini diterjemahkan menjadi proses mendapatkan pengakuan, melalui proses penyadaran masyarakat sebagai kekuatan oposisi untuk dimobilisasi dalam aksi-aksi protes dengan tujuan mendorong perubahan kebijakan.

Berdasarkan hal di atas, maka sejumlah strategi kemungkinan dikembangkan untuk mendapatkan pengakuan dari negara. Hal yang paling mendasar adalah kepemilikan atas sumber daya alam, Ribot dan Peluso (2003) mengemukakan hak atas sumber daya alam, muncul sebagai klaim yang dilegitimasi oleh pengakuan sosial yang berwujud sebagai aturan adat, hukum dan kesepakatan. Pengakuan sosial ini merupakan kesepakatan yang menjadi titik tolak dari praktik hegemoni melalui tindakan represif dan koersif oleh negara (Peluso, 2006). Sehingga dengan adanya hak pengelolaan hutan komunitas, negara tidak bisa semenamena mengusir atau memindahkan komunitas di sekitar hutan karena masyarakat telah memiliki seperangkat hak dasar yang kuat dan terlegitimasi.

Hal lain yang ditunjukkan oleh Nancy Peluso (dalam Kidd, 2019:960) dengan memperkenalkan konsep pemetaan tandingan untuk menentang rencana tata guna lahan negara yang menggabungkan metode berteknologi rendah dengan memasukkan perspektif serta pengalaman hidup untuk menentang keadaan yang kurang beruntung guna mendapatkan pengakuan teritori atas sumber daya yang diakui oleh masyarakat umum. Peta tandingan ini sebagai alat protes dan konsolidasi bagi para aktivis bersama komunitas lokal yang berusaha mempertahankan tanah adatnya dari klaim teritori negara. (Peluso, 1995). Bagi masyarakat adat, tanah ulayat dan sumber daya alam merupakan unsur yang berkaitan dengan pembentukan identitas dan kelangsungan hidupnya. Mengingat masyarakat adat memiliki sifat yang melekat atas tanah dan sumber daya tradisional sebagai elemen hak untuk menentukan nasib sendiri (Northcott, 2012). Untuk itu klaim atas sumber daya dan penguasaan atas lahan diperlukan representasi politik dan artikulasi konseptual untuk komunitas yang diberdayakan dalam membuat klaim. Misalnya, gerakan global LSM telah menampilkan terminologi masyarakat adat sebagai argumen untuk melawan perampasan tanah dan sumber daya alam (Moniaga, 2010). Penggunaan terminologi masyarakat adat secara simultan dapat membantu membingkai perjuangan komunitas untuk mengklaim hak atas sumber daya alam, sehingga harus dipahami sebagai strategi politik yang fleksibel untuk melawan negara dalam daftar diskursif yang relatif aman.

\section{Metode Penelitian}

Penelitian ini menekankan pada metode kualitatif deskriptif dengan memposisikan peneliti sebagai instrumen penelitian artinya hubungan antara peneliti dan sumber data yang diperoleh (informan). Penggunaan metode ini untuk memberikan penjelasan dan memahami peristiwa yang sedang atau telah terjadi, yang menekankan pada interpretasi makna yang berkembang dari informan penelitian (Denzin \& Lincoln, 2011).

Pengumpulan data dilakukan dengan menentukan individu-individu dan tempat yang diteliti secara spesifik, serta memberi pemahaman tentang problem riset dan fenomena dalam studi tersebut (Creswell, 2013:217) peneliti memutuskan untuk menentukan teknik pengumpulan data dengan menentukan sampling dengan cara purposive guna menentukan informan yang diyakini dapat menjelaskan persoalan secara spesifik dengan pertimbangan memiliki kapasitas dan terlibat langsung dalam melakukan pengorganisasian di lapangan atau terlibat langsung dalam advokasi masyarakat maupun berbagai sumber yang berkaitan dengan aktivitas tersebut. Selain teknik purposive, peneliti juga menentukan siapa 
Mohamad Bustam - Peran Lembaga Swadaya Masyarakat dalam Penetapan Taman Nasional Lore Lindu: Studi Yayasan Tanah Merdeka dalam Memperjuangkan Hak Masyarakat Katu

dan di mana yang menjadi sumber informasi dengan menggunakan teknik snowball yakni, teknik pengambilan sumber data yang awalnya jumlahnya sedikit akan berkembang menjadi lebih banyak dan beragam untuk memperkaya informasi. Pemilihan informan dilakukan dengan menggabungkan kedua teknik tersebut, dengan jumlah informan sebanyak 15 orang yang terdiri dari 8 orang aktivis LSM, 3 orang dari pihak taman nasional dan 4 orang yang mewakili komunitas lokal. Kriteria informan adalah para aktivis LSM yang duduk sebagai pimpinan maupun staf, perwakilan dari pihak taman nasional serta, komunitas lokal yang memiliki pengetahuan dan informasi terhadap peran LSM dalam memperjuangkan hak komunitas lokal atas penetapan kawasan taman nasional. Penelitian dilakukan selama 2 bulan dimulai pada tanggal 14 Desember 2019 sampai dengan 10 Februari 2020, yang dilakukan pada dua lokasi yakni, di Palu dan Desa Katu Kecamatan Lore Tengah Kabupaten Poso.

Penelitian ini dilakukan dengan menempuh beberapa langkah yakni, Pertama, melakukan kunjungan pada lokasi penelitian Kedua, pengumpulan data dilakukan dengan wawancara mendalam pada informan kunci maupun wawancara bebas dengan beberapa staf LSM, maupun pihak taman nasional, serta Komunitas Orang Katu sembari mengumpulkan dokumen pendukung (data sekunder). Ketiga, melakukan analisis yang dimulai dengan reduksi data, kemudian mengelompokkan dalam kategori agar memudahkan untuk disajikan dan disimpulkan sebagai hasil dari penelitian untuk dilakukan verifikasi. Sebagaimana Miles \& Huberman (1992:20) menyatakan proses analisis data dilakukan dengan tiga tahap yakni reduksi dan kategori dan penyajian data, serta penarikan kesimpulan dan verifikasi.

\section{Hasil}

Sejak penetapan kawasan Taman Nasional Lore Lindu melalui Surat Keputusan Menteri Kehutanan No.593/Kpts-II/1993 tanggal 5 Oktober 1993 dengan luas 229.000 hektar, beredar kabar bahwa Komunitas Orang Katu direncanakan akan dipindahkan kembali, setelah pemerintah gagal memindahkan mereka pada tahun 1984, 1985, 1986. (Sangadji, 2002). Pada tahun 1997, rencana itu semakin jelas setelah Asian Development Bank (ADB) memberikan pinjaman kepada pemerintah Indonesia untuk mengembangkan Proyek Central Sulawesi Integrated Area Development and Conservation Project (CSIADCP) (Sangadji, 2002). Proyek tersebut mengharuskan Orang Katu untuk meninggalkan wilayahnya karena, wilayah Orang Katu berada dalam kawasan taman nasional dan kegiatan berladang mereka dianggap merusak lingkungan (Sangadji, 2002; D’Andrea, 2013).

Ketidakberdayaan masyarakat atas tekanan otoritas negara melalui kebijakan dipandang sebagai sebuah proses hegemoni melalui koersi oleh negara (Simon, 1999; Sugiono, 2006). Pada titik inilah Yayasan Tanah Merdeka (YTM) menawarkan bantuan kepada Komunitas Orang Katu untuk memperjuangkan hak atas sumber daya alamnya. Sebagaimana Tania Murray Li (2012: 259) menyatakan gerakan LSM yang kuat di Palu terkait erat dengan perjuangan nasib penduduk pedesaan, seiring meningkatnya pengusiran dengan kekerasan, pembakaran tanaman, gubuk serta penangkapan penduduk. Penelitian ini menunjukkan peran YTM dalam memperjuangkan hak Komunitas Orang Katu dilakukan dalam dua cara, yakni membentuk kesadaran kolektif dan melibatkan Komunitas Orang Katu dalam ranah aktivisme, serta strategi yang dikembangkan dalam tiga tahapan yakni penyusunan dokumen pemanfaatan sumber daya alam, pembuatan peta wilayah pemanfaatan dan penggunaan terminologi masyarakat adat sebagai instrumen perjuangan.

\section{Membentuk Kesadaran Kolektif}

Proses penyadaran Komunitas Orang Katu oleh para aktivis dilakukan melalui beberapa tahap. Pertama, melakukan diskusi bersama komunitas guna menggali seluruh informasi tentang dampak dan ancaman penetapan TNLL. Secara bergantian Orang Katu menyampaikan seluruh keluhannya atas kondisi yang mereka hadapi. Misalnya, pelarangan berladang, memungut hasil hutan, hingga rencana relokasi ke wilayah Rompo. Pada tahap ini, para aktivis mengagitasi masyarakat dengan membenturkan pengalaman dan praktek sehari-hari komunitas dengan konsekuensi dari penetapan TNLL. Kedua, para aktivis memberikan pendidikan politik kepada Komunitas Orang Katu tentang hak dan kewajibannya sebagai warga negara, serta mendalami kepentingan yang mendasar dari penetapan kawasan TNLL. Rangkaian ini menghubungkan memori kolektif komunitas dengan struktur negara untuk memahami 
posisi mereka dalam dinamika kebijakan pembangunan. Sehingga memberi kemampuan pada komunitas untuk mengidentifikasi tentang siapa yang diuntungkan dan dirugikan dari proyek konservasi. Sehingga memunculkan polarisasi "kami dan mereka" antara Komunitas Orang Katu terhadap pihak TNLL. Ketiga, membentuk identitas kolektif Orang Katu sebagai instrumen penghubung antar individu dalam komunitas dengan rasa, kesamaan tujuan, dan tindakan yang diejawantahkan dalam aksi kolektif. Identitas ini berkaitan erat dengan kesadaran komunitas untuk menempatkan diri dan memberikan arti dan makna kepada pihak luar, tentang praktek-praktek sosial dan hubungannya dengan sumber daya alam yang dimiliki, sehingga dapat menggambarkan komunitas sebagai sesuatu yang unik dan berbeda dari masyarakat umum.

Proses penyadaran komunitas berlangsung cukup lama, proses dimulai sejak periode 19971998, mengingat rendahnya tingkat pendidikan masyarakat serta akses menuju lokasi hanya bisa ditempuh dengan jalan kaki. Berbagai kendala tersebut dengan terbentuknya kemampuan komunitas dalam menghubungkan masalah keterbatasan sumber daya alam dalam struktur negara. Tidak jarang dari mereka memiliki kemampuan berkomunikasi dengan pihak luar melalui forum-forum diskusi secara internal maupun eksternal. Dalam berbagai pertemuan bersama pemerintah, komunitas orang Katu berpartisipasiaktif dalam menyampaikan pendapat maupun protes, tentang hak-haknya sebagai masyarakat asli yang memiliki nilai-nilai kearifan lokal dalam pemanfaatan sumber daya alam di wilayahnya. Secara simultan kesadaran yang diperoleh Komunitas Orang Katu bertransformasi menjadi tindakan perlawanan dalam bentuk aksi kolektif yang didasarkan pada rasa ketidakadilan atas pengaturan negara terhadap sumber daya alam yang dimiliki secara turun-temurun.

\section{Melibatkan Komunitas Dalam Gerakan di Tingkat Lokal}

Proses penyadaran Komunitas Orang Katu atas tekanan yang dihadapi, telah membentuk serangkaian tindakan menolak penetapan kawasan TNLL. Penolakan ini tidak hanya terjadi pada Komunitas Orang Katu, namun di beberapa tempat komunitas lokal yang berbatasan langsung dengan TNLL. Terdapat lebih dari 60 desa tersebar di dua kabupaten yakni, Kabupaten Poso dan Kabupaten
Sigi yang tumpang tindih dengan kawasan TNLL (Sangadji, 2002:53). Sehingga, penolakan tersebut berujung pada aksi protes bersama oleh beberapa komunitas yang hidup di sekitar TNLL. Pada tahun 1999, protes yang berlangsung di depan Gedung DPRD dan Gubernur Provinsi Sulawesi Tengah, melibatkan masyarakat dari Bungku (Kabupaten Morowali), Katu dan Doda (Kabupaten Poso), Lindu dan Tompu (kabupaten Sigi), Kayumalue (Kabupaten Donggala) dan Dondo (Kabupaten Tolitoli) (Sangadji dalam Moniaga 2010). Komunitas Orang Katu Meskipun mengalami penghadangan oleh petugas kepolisian dan TNI, beberapa orang dalam berhasil meloloskan diri untuk bergabung dalam aksi protes di kota Palu (Bustam \& Damanik, 2020). Dalam aksinya mereka menuntut agar tidak dipindahkan dan diakui keberadaannya oleh pemerintah. Kehadiran beberapa komunitas dalam melakukan aksi serupa, dipandang YTM sebagai bentuk ketersediaan "sumber daya" dalam menciptakan aksi kolektif yang lebih besar. YTM mendorong komunitas Orang Katu, agar terhubung dengan ikatan-ikatan solidaritas dari pihak eksternal. Sehingga, dapat mengintegrasikan keluhan, tuntutan dan tujuan bersama komunitas dalam rangkaian gerakangerakan melawan ketidakadilan negara dalam pemanfaatan sumber daya alam.

Sepanjang periode 1998-1999, bersamaan dengan lengsernya rezim Orde Baru, aksi-aksi protes komunitas lokal terhadap pemerintah semakin menguat. Kondisi ini dipicu oleh hubungan yang dibangun oleh para aktivis YTM bersama WALHI sebagai mitra dalam membicarakan kemungkinan strategi-strategi yang dikembangkan untuk menekan pemerintah agar mengakui keberadaan komunitas lokal di tengah situasi politik nasional yang tidak stabil. Aktivis menyebarluaskan aksi protes yang dilakukan oleh komunitas melalui propaganda media, untuk menciptakan kemungkinan adanya pihak eksternal yang ikut berpartisipasi dalam mendukung aksi protes terhadap pemerintah. Dalam proses ini, YTM memainkan peran dengan memperjelas isu dan mengembangkan jaringanjaringan sebagai bentuk dukungan dan sumber daya yang dapat dimobilisasi ke dalam gerakan komunitas adat.

Secara umum, pelibatan Orang Katu dalam gerakan dilakukan melalui beberapa langkah pertama, menyelaraskan dan mensinergikan aksi mereka dengan komunitas yang memiliki isu serupa. hal itu tidak hanya diperlihatkan 
Mohamad Bustam - Peran Lembaga Swadaya Masyarakat dalam Penetapan Taman Nasional Lore Lindu: Studi Yayasan Tanah Merdeka dalam Memperjuangkan Hak Masyarakat Katu

Gambar 1

Protes Masyarakat Adat periode 1998-1999

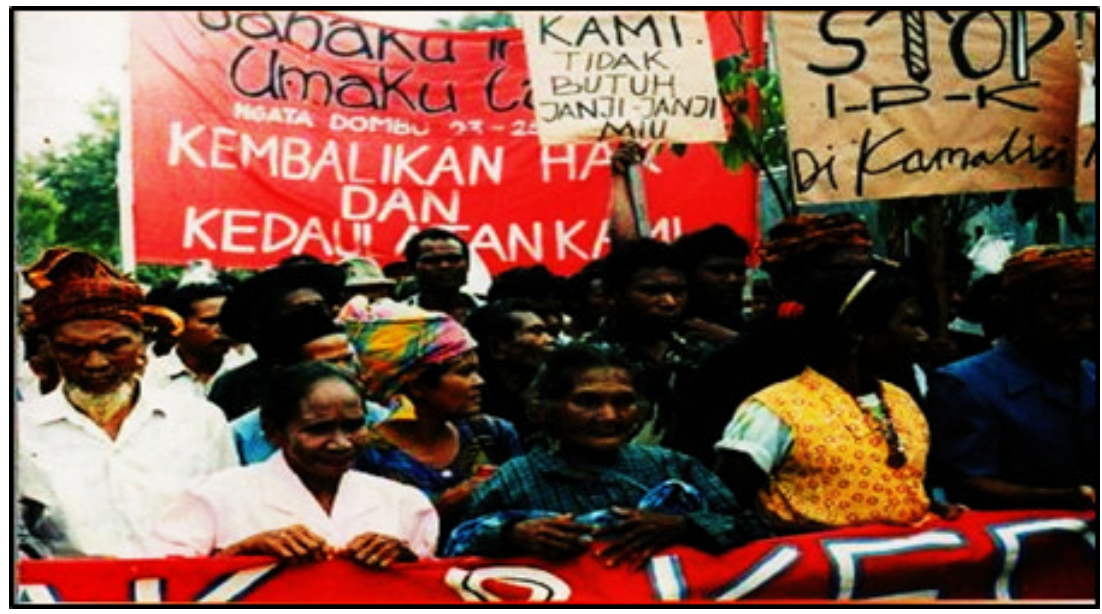

Sumber: Dokumentasi Yayasan Tanah Merdeka, 1999

ketika kepercayaan diri beberapa perwakilan Komunitas Orang Katu dalam mengemukakan pendapat di hadapan pemerintah, tetapi juga menandakan kemampuan mengorganisir dirinya untuk berinteraksi dengan pihak luar agar konsistensi gerakan tetap terjaga. Kedua, melakukan konsolidasi dengan LSM lokal, serta menyebarkan isu yang sedang dihadapi komunitas ke ruang publik melalui pemberitaan media lokal. Dengan demikian, proses ini mengantarkan komunitas Orang Katu terlibat secara langsung dalam gerakan bersama komunitas lainnya serta, terhubung dengan organisasi gerakan seperti WALHI.

Pelibatan Komunitas Orang Katu dalam gerakan di tingkat lokal, secara tidak langsung telah memperkuat ikatan solidaritas antar komunitas yang hidup di bawah ancaman penetapan TNLL. Tahapan ini, mampu menggerakkan kondisi keresahan dan frustrasi dalam diri masing-masing komunitas yang terintegrasi dalam rasa kebersamaan dengan berbagai komunitas yang memiliki nasib serupa. tak jarang mereka mulai menggunakan narasi-narasi identitas "masyarakat adat" sebagai identitas kolektif dalam bingkai gerakan menentang kebijakan penetapan TNLL untuk memperoleh dukungan dari berbagai pihak.

\section{Menyusun Sistem Pengelolaan Sumber daya Alam Orang Katu \\ Strategi ini merupakan proses penciptaan instrumen yang berasal dari memori kolektif komunitas sebagai model tandingan pengelolaan}

sumber daya alam antara komunitas lokal dan otoritas TNLL. Sekaligus berusaha memantapkan klaim kepemilikan atas sumber daya alam yang dimiliki secara turun-temurun. Hal ini, dilakukan dengan melibatkan seluruh komunitas Orang Katu, untuk menggali "memori kolektif" tentang praktek-praktek dan aktivitas mereka dalam memperlakukan alam sebagai ruang hidupnya. Melalui pendokumentasian secara rinci sistem kepemilikan lahan, cara mengelola lahan, serta pemanfaatan hasil hutan. Sehingga, proses ini menggambarkan hubungan perjuangan yang bersifat kultural dan material atas wilayah. Dengan kata lain, sebagai proses

Tabel 1

Pemanfaatan Tanah Komunitas Katu

\begin{tabular}{cl}
\hline $\begin{array}{c}\text { Kepala } \\
\text { Keluarga }\end{array}$ & Pemanfaatan \\
\hline 12 & Hinoe, bonde, cokelat, kopi \\
6 & Hinoe, kopi, cokelat \\
8 & Bonde, kopi, cokelat \\
10 & Bonde, kopi \\
5 & Hinoe, bonde, kopi \\
1 & Hinoe, cokelat \\
1 & Kopi, cokelat \\
2 & Bonde, cokelat \\
2 & Hinoe, kopi \\
1 & Cokelat \\
6 & Bonde \\
2 & Hinoe \\
3 & Cokelat \\
4 & Tidak mengolah tanah \\
& Sumber: Sangadji, 2002
\end{tabular}


Tabel 2

Hasil inventarisasi jenis rotan di Bulu Ngkanino (wilayah adat Orang Katu seluas 94 hektar)

\begin{tabular}{|c|c|c|c|c|c|c|}
\hline Jalur & Jumlah plot & Hilako & Pai & Gopa & Pute & Tohiti \\
\hline 1 & 4 & 98 & 1029 & 0 & 0 & 41 \\
\hline 2 & 13 & 1238 & 3076 & 80 & 3 & 1010 \\
\hline 3 & 13 & 505 & 2634 & 80 & 1 & 814 \\
\hline 4 & 16 & 0 & 4354 & 239 & 1 & 1259 \\
\hline 5 & 15 & 29 & 5743 & 570 & 1 & 1597 \\
\hline 6 & 14 & 0 & 1392 & 488 & 1 & 1033 \\
\hline 7 & 18 & 0 & 1583 & 1015 & 3 & 26 \\
\hline 8 & 18 & 0 & 137 & 50 & 3 & 3 \\
\hline 9 & 9 & 0 & 6 & 0 & 39 & 0 \\
\hline Total & 120 & 1870 & 19954 & 2512 & 52 & 5783 \\
\hline
\end{tabular}

Catatan:

1. Jalur adalah rute inventarisasi

2. Plot adalah areal inventarisasi seluas $5 \times 10 \mathrm{~m}$

Sumber: Sangadji, 2002

mengintegrasikan identitas kolektif dan tujuan perjuangan menjadi kekuatan yang konstitutif dalam arena gerakan.

Proses penyusunan dokumen ini dilakukan di Desa Katu melalui lokakarya yang diselenggarakan oleh para aktivis tentang perencanaan pengelolaan sumber daya alam. Pada tahap ini, masyarakat menceritakan sejarah keberadaan dan mendeskripsikan praktikpraktik pengelolaan sumber daya alamnya, seperti pola berladang dan pemanfaatan hasil hutan, sistem kepemilikan, penyelesaian sengketa tanah, serta membuat daftar tumbuh-tumbuhan dan sumber daya alam liar menggunakan bahasa lokal.

Praktik-praktik pengelolaan sumber daya alam ini, juga dikuatkan dengan membentuk sejumlah aturan dan sanksi sebagai langkah untuk mewujudkan sistem pengelolaan sumber daya alam secara lestari dan berkelanjutan. Dalam praktiknya, mereka tidak mengizinkan pihak luar untuk melakukan aktivitas pengambilan hasil hutan di wilayahnya, seperti pengambilan beberapa jenis hasil hutan yang keberadaannya sangat langka atau melakukan transaksi jual beli tanah, baik internal maupun eksternal komunitas (YTM, 2011). Hal ini menegaskan bahwa, komunitas memiliki kesadaran untuk memperoleh legitimasi negara. Kesadaran ini tidak hanya terlihat dalam praktik pengelolaan sumber daya alam Orang Katu, tetapi juga dikuatkan oleh pemberlakuan sanksi tegas terhadap internal dan eksternal komunitas.

Serangkaian proses ini, dikemas dan ditampilkan ke ruang publik oleh para aktivis melalui media internal YTM, yakni "Seputar Rakyat". YTM membuat dokumen berjilid dengan memuat beberapa gambar komunitas Orang Katu untuk tampilkan di sampul depan. Hal ini, dilakukan oleh para aktivis untuk menyampaikan pesan kepada pihak eksternal, bahwa komunitas Orang Katu memiliki nilai-nilai kearifan lokal dalam praktik-praktik pemanfaatan sumber daya alamnya yang terorganisasi secara baik. Bagi para aktivis, pembuatan dokumen ini bertujuan untuk menciptakan alat koordinasi antara masyarakat dan pihak luar, serta menjadi pedoman komunitas untuk melaksanakan pembangunan dan pengelolaan sumber daya alam secara berkelanjutan. Dalam menerapkan aturan ini, para aktivis mendorong komunitas untuk memfungsikan kembali lembaga adat sebagai otoritas yang melakukan kontrol, pengawasan dan pengendalian praktik-praktik pengelolaan hutan komunitas. Dengan demikian, ketersediaan dokumen ini dalam internal komunitas Orang Katu, telah membentuk sistem pengelolaan sumber daya alam yang berbasis basis pengetahuan lokal (praktek sehari-hari) yang bertujuan menandingi sistem pengelolaan sumber daya alam Taman Nasional, penggunaan strategi ini, tidak lain sebagai usaha untuk memantapkan klaim kepemilikan sumber daya alamnya, sekaligus menjawab stigma-stigma buruk yang selalu disematkan kepada komunitas lokal.

\section{Pemetaan Partisipatif}

Guna melengkapi dokumen-dokumen tentang sistem dan praktik pengelolaan 
Mohamad Bustam - Peran Lembaga Swadaya Masyarakat dalam Penetapan Taman Nasional Lore Lindu: Studi Yayasan Tanah Merdeka dalam Memperjuangkan Hak Masyarakat Katu

sumber daya alam komunitas, para aktivis YTM mendorong komunitas untuk membuat peta wilayahnya, sehingga dapat meneguhkan klaim-klaim mereka dalam bentuk yang lebih spesifik, terkait posisi dan letak geografis komunitas. Hal ini disebut Peluso (1995) sebagai "peta tandingan" untuk memformalkan klaim-klaim komunitas lokal atas sumber daya, sehingga secara simultan menandingi monopoli negara atas wilayah komunitas. Strategi ini merupakan pilihan yang rasional untuk mengontrol wilayah dari ancaman pihak luar yang ingin memanfaatkan kekayaan sumber daya alam Komunitas Orang Katu. Dalam proses pembuatan peta ini, para aktivis YTM bekerjasama dengan sebuah LSM yang bergelut di bidang pemetaan wilayah komunitas lokal, yakni Jaringan Kerja Partisipatif (JKPP). Secara bersama-sama, mereka memberikan pelatihan kepada beberapa masyarakat Katu untuk menggunakan peralatan-peralatan pembuatan peta, seperti kompas, GPS, dan alat tulis.

Proses pemetaan dilakukan secara berkelompok, peserta membuat sketsa yang memuat jalan, sungai, tempat berladang, tempat mengumpulkan hasil hutan-seperti rotan, getah damar, kayu, ramuan obat-obatantempat berburu, serta batas-batas yang diklaim milik masyarakat adat Katu. Beberapa orang yang telah diajarkan menggunakan Global Positioning System (GPS), kompas dan alat dokumentasi mulai melakukan survei lokasi dan menentukan titik koordinat yang dituangkan dalam peta tertulis. Seluruh proses pemetaan dilakukan selama dua bulan. Dimulai dengan menuliskan nama-nama sungai, gunung di sekitar wilayahnya dengan menggunakan bahasa setempat, serta memberikan tanda pada tempat mengumpulkan hasil hutan dan mengelompokkan jenis hutan pada tiap zona wilayah tersebut dengan pendokumentasian secara rinci.

Kehadiran peta ini merupakan bentuk klaim history cultural komunitas untuk menunjukkan adanya perbedaan ruang tempat mereka hidup yang tumpang tindih dengan kawasan taman nasional. Kuasa komunitas atas teritori melalui peta partisipatif merupakan proses pemetaan tandingan atas peta yang dibuat oleh TNC dan pihak TNLL, yang dilengkapi dengan dokumen pengelolaan sumber daya alam Komunitas Orang Katu yang mempraktikkan nilai-nilai pelestarian lingkungan. Dalam beberapa forum-forum dialog dengan pemerintah daerah, seluruh dokumen ini dipresentasikan kepada pihak Balai Taman Nasional Lore Lindu dan TNC, sebagai pihak yang menginginkan perpindahan mereka dari wilayahnya, meskipun pihak Balai Taman Nasional dan TNC menganggap peta yang mereka buat tidak cukup menjadi representasi tentang penguasaan sumber daya alamnya.

Dengan demikian, terdapat dua hal penting dalam melihat strategi pemetaan oleh para aktivis dan Komunitas Orang Katu. Pertama, melalui peta tersebut, secara internal komunitas Orang Katu telah memiliki bukti

Gambar 2

Peta Wilayah Pemanfaatan Orang Katu

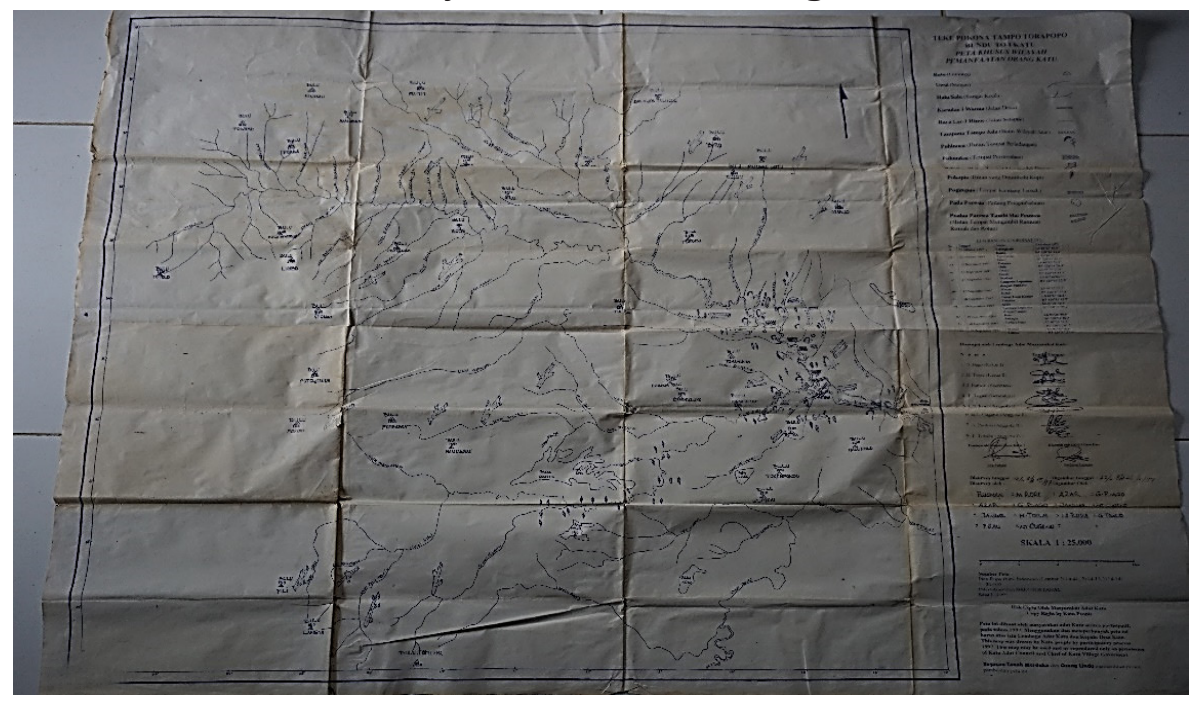

Sumber: Bustam \& Damanik, 2020 
yang membenarkan batas-batas lokasi atau tempat mereka melakukan praktik-praktik pengelolaan sumber daya alamnya. Kedua, ketersediaan peta dan kelengkapan dokumendokumen pengelolaan sumber daya alamnya dapat menjadi alat konsolidasi komunitas secara internal dan eksternal untuk menjelaskan kepada berbagai pihak tentang sistem dan model pengelolaan lahan, sekaligus membantah stigma-stigma yang disematkan kepada mereka sebagai perusak hutan.

\section{Terminologi Masyarakat Adat Sebagai Instrumen Perjuangan}

Serangkaian strategi dan taktik yang dikembangkan oleh para aktivis bersama Komunitas Orang Katu, memperlihatkan bagaimana identitas dan kepentingan bersama yang saling menguatkan. Dengan kata lain, proses ini merupakan sebuah bentuk produksi identitas kolektif yang ditampilkan sebagai ekspresi kekesalan terhadap negara. Hal ini, dilakukan dengan membingkai persoalan yang mereka hadapi sebagai isu perjuangan identitas "masyarakat adat" dalam menuntut pengakuan hak-hak atas sumber daya alam. Meskipun, penggunaan terminologi masyarakat adat semula dimaksudkan untuk memperkuat solidaritas secara internal dan eksternal dengan berbagai komunitas lokal di sekitar TNLL

Keterlibatan Komunitas Orang Katu, dalam gerakan di tingkat lokal, secara tidak langsung telah membentuk kekuatan dan memperoleh dukungan dari pihak lain untuk menjangkau kepentingannya. Pada tahapan ini, terlihat kecenderungan para aktivis YTM menggerakkan Komunitas Orang Katu untuk masuk ke dalam wacana masyarakat adat. Hal ini dapat dilihat pada penguatan identitas kolektif dalam setiap strategi yang dikembangkan, seperti, penyusunan pengelolaan sumber daya alam berbasis pengetahuan lokal, serta membuat peta tandingan wilayah. Selain, merupakan usaha untuk meneguhkan klaim kepemilikan komunitas atas sumber daya alamnya, proses ini juga menunjukkan bahwa bukti kepemilikan yang didasarkan pada identitas komunitas merupakan narasi yang koheren dalam menghasilkan cerita yang meyakinkan, untuk menjelaskan klaim atau mengesahkan pengakuan terhadap hak atas sumber daya alamnya. Sehingga penggunaan narasi-narasi identitas atau masyarakat adat dapat membantu komunitas untuk memperoleh legitimasi.
Secara simultan, penggunaan narasi-narasi identitas ini memiliki konsekuensi tersendiri. Misalnya, sebagian besar komunitas lokal yang wilayahnya berbatasan langsung dengan TNLL, mengidentifikasi dirinya sebagai masyarakat adat. Hal ini, tanpa disadari mengakibatkan eksklusivisme penduduk yang berstatus sebagai pendatang di sekitar Lembah Besowa. Namun, bagi para aktivis penggunaan terminologi ini bukan didasarkan pada semangat etnosentris, tetapi sebagai bentuk menjalin solidaritas antar komunitas lokal untuk mendapatkan hak-hak mereka atas penetapan kawasan TNLL.

Tabel 3

Komunitas Masyarakat Adat Sulawesi Tengah yang meminta pengakuan dan verifikasi, serta penyebarannya berdasarkan Kabupaten

\begin{tabular}{cccc}
\hline Provinsi & $\begin{array}{c}\text { Melamar } \\
\text { sebagai } \\
\text { kandidat }\end{array}$ & $\begin{array}{c}\text { Diverifikasi } \\
\text { dan } \\
\text { diterima }\end{array}$ & $\begin{array}{c}\text { Penyebaran } \\
\text { dalam jumlah } \\
\text { kabupaten }\end{array}$ \\
\hline $\begin{array}{c}\text { Sulawesi } \\
\text { Tengah }\end{array}$ & 86 & 81 & 10 \\
\hline
\end{tabular}

Sumber: Acciaoli dalam Moniaga, 2010

Terminologi masyarakat adat dinarasikan sedemikian rupa untuk menguatkan klaim dan menjustifikasi aksi. Narasi yang disampaikan meneguhkan memori kolektif komunitas tentang akses sumber daya alam yang diakui sebelumnya, namun dalam waktu tertentu akses tersebut dibatasi. Dengan demikian, proses ini merupakan usaha menghubungkan praktek-praktek komunitas dengan realitas yang disajikan melalui narasi identitas untuk membenarkan klaim atau aksi kolektif sebagai proses untuk mendapatkan kembali hak-hak atas sumber daya alam. Rangkaian aksi protes komunitas adat di sekitar TNLL, dipublikasikan oleh aktivis YTM melalui pertemuan-pertemuan aktivis di tingkat lokal dan sejumlah jaringan kerja di tingkat pusat, seperti WALHI, KPSHK, dan JKPP. Hal ini dilakukan untuk menggalang dukungan dan mendesak pemerintah agar mengeluarkan Undang-Undang perlindungan terhadap komunitas masyarakat adat. Sehingga, komunitas dapat menjangkau hakhak kepemilikannya yang didasarkan pada hak politik, ekonomi, dan kultural komunitas adat sebagai warga negara.

Bersamaan dengan aksi-aksi protes komunitas lokal di Sulawesi Tengah, tepatnya pada bulan Maret 1999, Kongres Masyarakat Adat Nasional ke-I (KMAN I) di Jakarta dan dilanjutkan 
Mohamad Bustam - Peran Lembaga Swadaya Masyarakat dalam Penetapan Taman Nasional Lore Lindu: Studi Yayasan Tanah Merdeka dalam Memperjuangkan Hak Masyarakat Katu

dengan melahirkan Aliansi Masyarakat Adat Nusantara (AMAN) (Acciaioli, 2010:327). Setelah KMAN I di Jakarta, tepatnya tanggal 16 Mei 2000, kongres pertama Aliansi Masyarakat Adat Sulawesi Tengah (AMASUTA) berhasil dilakukan dengan dihadiri 100 perwakilan komunitas adat dari berbagai daerah di Sulawesi Tengah. Banyak dari mereka yang hadir dalam kongres AMASUTA memiliki persoalan yang sama, yakni terlibat konflik dengan pemerintah dan perusahaan-perusahaan ekstraksi sumber daya alam (Sangadji, 2010:362). Kehadiran AMASUTA yang mewadahi komunitas masyarakat adat di Sulawesi Tengah mencerminkan transisi gerakan mereka dari yang sebelumnya meminta pengakuan negara menuju pelaksanaan artikulasi sosial dan politik di tingkat lokal. Melihat gerakan-gerakan identitas AMASUTA yang semakin meluas di Sulawesi Tengah, para aktivis mendorong komunitas Orang Katu untuk terlibat dalam organisasi AMASUTA untuk menjangkau hak-hak mereka.

\section{Diskusi}

Peran dan strategi YTM dalam menciptakan hegemoni tandingan merupakan suatu usaha dalam memperkuat posisi tawar masyarakat di hadapan negara. YTM memulai dengan melakukan kerja pengorganisasi dengan membentuk kesadaran kolektif dan melibatkan komunitas dalam ranah aktivisme sebagai proses penyebaran ideologi, sebagaimana penjelasan Gramsci (1971) yang meletakkan kekuatan ide (ideologi) dan kesadaran kolektif sebagai penggerak perubahan sosial (Simon, 1999:8687), sebuah proses dialektis dari praksis refleksi dan tindakan - dimana seseorang melihat ketidaksetaraan sosial sebagai fabrikasi yang dapat dibongkar melalui tindakan kolektif manusia (Kwon, 2008), dengan menyusun pengalaman pribadi tentang ketidakadilan dan memandang penindasan bukan sebagai dunia yang tertutup, tetapi sebagai situasi dimana seseorang dapat menemukan jalan keluar (Freire, 1996). Hal ini merupakan sebuah proses transformasi masyarakat lokal yang sebelumnya tidak menamakan diri sebagai "masyarakat adat" dan bergabung dalam organisasi-organisasi gerakan.

Guna menyelaraskan tindakan tersebut, para aktivis membuat beberapa poster kampanye, poster tersebut mengisahkan perjalanan panjang komunitas yang tersingkir dengan adanya penetapan kawasan TNLL. Secara bersamaan aksi-aksi mereka juga menjadi headline di beberapa media lokal, nasional bahkan internasional. Beberapa media yang meliput aksi-aksi mereka diantaranya Media Kompas, Mercusuar, Media Al Khairat, Bisnis Indonesia, serta Down to Earth (Sangaji, 2002:46-53). Pada tahap ini LSM menjadi agen intelektual organik yang mempengaruhi pengambil kebijakan melalui saluran-saluran politik seperti Media. Langkah ini disebut Gramsci sebagai langkah meng-counter hegemoni negara. Selanjutnya dalam rangkaian counter hegemoni, aktivis YTM bersama Komunitas Orang Katu menyusun strategi dalam 3 tahapan yakni, 1) Penyusunan dokumen pemanfaatan sumber daya alam, merupakan proses pembentukkan instrumen yang berasal dari memori kolektif komunitas sebagai model tandingan dari praktik-praktik pengelolaan sumber daya alam yang berkelanjutan antara komunitas lokal dan otoritas TNLL, sekaligus berusaha memantapkan klaim kepemilikan atas sumber daya alam yang dimiliki secara turun-temurun, 2) pembuatan peta partisipatif yakni, secara internal komunitas Orang Katu telah memiliki bukti yang membenarkan batas-batas lokasi atau tempat mereka melakukan praktik-praktik pengelolaan sumber daya alamnya, serta dilengkapi dengan dokumen pengelolaan sumber daya alam untuk menjelaskan kepada berbagai pihak tentang sistem dan model pengelolaan lahan, sekaligus membantah stigma-stigma yang disematkan kepada mereka sebagai perusak hutan, 3) penggunaan terminologi masyarakat adat. Digunakan menyelaraskan pemahaman secara nasional dan internasional tentang indigenous people, dalam konvensi ILO 168 tentang hakhak masyarakat adat. Hal ini dimanfaatkan oleh aktivis untuk menarik perhatian dengan dunia luar, tidak hanya penyandang dana, tetapi juga sejumlah LSM pada tingkat lokal dan nasional juga ikut menyuarakan tuntutan komunitas adat. Sehingga gerakan-gerakan hak masyarakat adat atas sumber daya alam mampu menjangkau wacana hak global.

Konsolidasi terus menerus dari para aktivis dan komunitas masyarakat adat dalam aksi protes, dan jajak pendapat dengan TNC dan pihak Taman nasional, pada akhirnya komunitas Orang Katu melalui Kepala Balai Taman Nasional Ir. Banjar Julianto, mempelajari sistem pertanian dan pola produksi komunitas Orang Katu. 
Pada 8 April 1999, Banjar mengeluarkan Surat Keputusan Nomor 35/VI-BTNLL.1/1999 yang mengakui keberadaan masyarakat Katu sebagai masyarakat adat dan memiliki hak atas tanah seluas 1.178 ha, serta sistem pengelolaannya yang menjadi bagian dari TNLL.

Meskipun menuai keberhasilan dalam gerakan, namun tidak dapat dihindarkan kelalaian sejumlah aktivis yang meleluasakan komunitas Orang Katu untuk mengklaim hutan menjadi hak komunitas yang berdasar pada bukti historis. Di saat yang Sama komoditi ekspor seperti Kopi dan Kakao menjadi komoditas primadona petani di Sulawesi Tengah (Li, 2012). Selain itu, penggunaan terminologi masyarakat adat dikhawatirkan menimbulkan eksklusivisme antara komunitas lokal dan pendatang, sekaligus pembentukan modal (kepemilikan tanah) yang dilakukan secara tidak sengaja oleh komunitas dengan gaung "adat" (D’Andrea, 2013). Meskipun sebagian besar aktivis YTM menyatakan bahwa perjuangan dilakukan bukan atas semangat etnosentris melainkan dalam rangkaian klaim atas sumber daya alam.

Terlepas dari dinamika tersebut, sebagai intelektual organik YTM setidaknya telah mengantarkan Komunitas Orang Katu mendapatkan pengakuan dari institusi negara serta berhasil memberikan homogenitas dan kesadaran tidak hanya pada aspek ekonomi tetapi juga di bidang sosial dan politik pada Komunitas Orang Katu. Selain itu bentuk LSM dalam isuisu seputar keadilan pemanfaatan sumber isu tertentu sangat dibutuhkan sebagai ruang antara masyarakat dan negara. penggunaan terminologi ini bertujuan untuk membentuk jaringan dan partisipan gerakan yang didasarkan pada identitas. Hal ini dapat dilihat ketika narasi masyarakat adat didengungkan oleh komunitas maupun para aktivis dalam aksi protes maupun saat wawancara dengan media. Secara tidak langsung, proses ini juga menguatkan rasa solidaritas antar jaringan gerakan serta partisipan yang ikut bergabung dalam aksi komunitas.

\section{Kesimpulan}

Peran YTM dalam memperjuangkan kepentingan masyarakat Katu, dilakukan dengan memposisikan dirinya sebagai intelektual yang mendorong masyarakat Katu masuk ke dalam ranah aktivisme melalui pembentukan aksi kolektif untuk melakukan protes dan menuntut pengakuan wilayah komunitas di hadapan negara atas penetapan TNLL.

Pembentukan aksi kolektif tersebut dilakukan dalam dua tahap. Pertama, membentuk kesadaran kolektif. Hal ini dilakukan dengan mengintegrasikan memori kolektif komunitas terhadap realitas -- kondisi ketidakadilan dan keterasingan - dari kebijakan penetapan TNLL, sehingga menghasilkan identitas kolektif yang didasari kesamaan, rasa, ide, tujuan dan tindakan bersama sebagai kelompok tertindas. Kedua, melibatkan komunitas dalam gerakan tingkat lokal dengan menghubungkan rasa keresahan dan frustrasi dalam diri masingmasing komunitas untuk mencapai tujuan bersama, agar aksi kolektif komunitas tidak terjebak pada tujuan jangka pendek, akan tetapi mampu menjangkau tujuan jangka panjang dengan melebur menjadi satu kesatuan antara identitas dan tujuan perjuangan, sehingga menjadi kekuatan yang konstitutif dalam arena politik pengelolaan sumber daya alam.

Serangkaian strategi yang dikembangkan oleh YTM dalam memperjuangkan hak Orang Katu, dilakukan dengan menghubungkan praktek-praktek sosial komunitas yang bersifat kultural dan material (SDA) ke dalam agenda perjuangan untuk ditampilkan kepada negara yakni otoritas TNLL, sebagai bentuk tandingan pengelolaan sumber daya alam. Sekaligus memperkuat solidaritas komunitas dengan menggunakan narasi-narasi masyarakat adat untuk menjangkau wacana hak global, sebagai instrumen untuk mendapatkan legitimasi negara. Secara spesifik strategi tersebut dilakukan dengan cara, Pertama, menyusun dokumen pengelolaan sumber daya alam sebagai strategi untuk memantapkan klaim "history cultural" komunitas, melalui pendokumentasian secara rinci tentang praktekpraktek pengelolaan lahan, dan pemanfaatan hasil hutan berbasis pengetahuan lokal. Kedua, membuat peta partisipatif. Dilakukan dengan mengambil perangkat teritorialisasi negara untuk membantu komunitas Orang Katu memformalkan klaim-klaim terhadap wilayahnya, sehingga mampu menandingi klaim negara dalam penetapan TNLL. Hal ini dilakukan dengan menuliskan batas-batas wilayah kelola, tempat atau lokasi berladang, dan tempat mengumpulkan hasil hutan, baik kayu maupun non kayu dalam peta tertulis, untuk ditampilkan sebagai bentuk penguasaan komunitas atas 
Mohamad Bustam - Peran Lembaga Swadaya Masyarakat dalam Penetapan Taman Nasional Lore Lindu: Studi Yayasan Tanah Merdeka dalam Memperjuangkan Hak Masyarakat Katu

wilayahnya. Ketiga, terminologi masyarakat adat sebagai instrumen perjuangan. Hal ini dilakukan dengan mengaitkan identitas komunitas Orang Katu pada narasi global sebagai indigenous people atau masyarakat adat, sehingga dapat melegitimasi aksi-aksi kolektif komunitas dalam menuntut pengakuan hak atas sumber daya alamnya di hadapan negara.

Strategi yang dilakukan YTM dalam memperjuangkan hak Komunitas Orang Katu, secara keseluruhan mampu membentuk kekuatan politik yang didasarkan pada identitas komunitas sebagai masyarakat adat. Dengan menempatkan praktek-praktek pengelolaan sumber daya alam berbasis pengetahuan lokal, serta peta wilayah adat komunitas, sebagai bentuk counter hegemoni dari klaim Negara atas kebijakan pemanfaatan sumber daya alam.

\section{Acknowledgement}

Artikel ini bersumber dari penulisan ringkas tesis penulis yang telah diuji sebagai persyaratan meraih gelar Master of Arts dari Departemen Pembangunan Sosial dan Kesejahteraan (PSdK), Fakultas Ilmu Sosial dan Ilmu Politik, Universitas Gadjah Mada pada tahun 2020.

\section{Referensi}

Alperstein, N.M. (2019). Social Movement: Our Virtual Collective Consciousness in: Celebrity and Mediated Social Connections. Cham: Palgrave Macmillan.

Azar, T. (2009). "Pemetaan Partisipatif: Mempertahankan Hak Atas Tanah Leluhur", dlm: Jaringan Kerja Pemetaan Partisipatif. (ed.), Menuju Demokratisasi Pemetaan: Refleksi Gerakan Pemetaan Partisipatif di Indonesia. Bogor: JKPP, pp. 72-93.

Banks, N., Hulme, D., Edward, M. (2015). NGOs, State, and Donors Revisited: Still Too Close for Comfort. World Development, 66, pp. 107-718.

Bustam, M., \& Damanik, J. (2020). Peran LSM Dalam Arena Konflik Pema nfaatan Lahan Di Kawasan Taman Nasional (Studi Pada Yayasan Tanah Merdeka Dalam Memperjuangkan Hak komunitas Orang Katu Di Sulawesi Tengah). Tesis, Universitas Gadjah Mada.

Cahyono, M. (2012). Aksi Petani dalam Kontestasi Politik Penataan dan Penguasaan Ruang di Kawasan Konservasi Taman Nasional
Ujung Kulon Provinsi Banten. Bogor: Institut Pertanian Bogor, Sosiologi Pedesaan.

Carroll, W., Ratner, R. (2010). Social Movements and Counter-Hegemony: Lessons from the Field. New Proposals: Journal of Marxism and Interdisciplinary Inquiry, 4 (1), pp. 7-22.

Choudry, A., Kapoor, D. (2013). NGOization: Complicity, Contradictions and Prospect. London: Zed Books.

Clark, J. (1995). NGO dan Pembangunan Demokrasi. Yogyakarta: PT Tiara Wacana.

Clarke, G. (1998). Non-Governmental Organization (NGOs) and Politics in the Developing World. Political Studies Association, 46(1), pp. 36-52. DOI: 10.1111/1476-9248.00128

Cresswell. J.W. (2013). Penelitian Kualitatif dan Desain Riset. (Edisi, Ketiga). Yogyakarta: Pustaka Pelajar.

D'Andrea, C. (2013). Kopi Adat dan Modal. Yogyakarta: Tanah Air Beta bekerjasama YTM dan Sajogyo Institute.

Denzin, N., Lincoln. (2011). The Sage Handbook of Qualitative Research. Edisi Ketiga, Yogyakarta: Pustaka Pelajar.

Eldridge, P. (1988). Non-Governmental Organisations and The Role of The State in Indonesia.

Fakih, M. (1996). Menggeser Konsepsi Gender dan Transformasi Sosial. Pustaka Pelajar.

Fakih, M. (2001). Masyarakat Sipil Untuk Transformasi Sosial: Pergolakan Ideologi LSM. Yogyakarta: Insist Press.

Femia, J. (1975). Hegemony and Consciousness in the Thought of Antonio Gramsci. Political Studies, 23(1), pp. 29-49. DOI:10.1111/j.1467-9248.tb00044.x

Girei, E. (2016). NGO's, Management and Development: Harnessing Counter Hegemony Possibilities. Organization Studies, 37(2), pp. 93-212. DOI: $10.1177 / 0170840615604504$

Giri, A. K., Ufford, P. Q. van. (2002). Kritik Moral Pembangunan. Yogyakarta: Kanisius.

Gottlieb, R. S. (1989). An Anthology of Western Marxism: From Lukács and Gramsci to Socialist-Feminism. Oxford University Press.

Hunt, A. (1990). Right and Social Movement: Hegemony strategies. Journal of Law and Society, 17(3), pp. 309-328. DOI: $10.2307 / 1410156$

Kelly, P.F. (2011). Migration, Agrarian Transition and Rural Change in Southeast Asia. Critical Asian Studies, 43(4), pp. 479-506. DOI: $10.1080 / 14672715.2011 .623516$ 
Kidd, D. (2019). Extra-activism: Countermapping and Data Justice. Information, Communication \& Society, 22(7), pp. 954-, 970. DOI: 10.1080/1369118X.2019.1581243

Kingsbury, B. (1998). "Indigenous People" in International Law: A Constructivist Approach to the Asian Controversy. The American Journal of International Law, 92(3), pp. 414-457. DOI:10.2307/2997916

Korten, D. C. (1987). Third generation NGO strategies: A key to people-centered development. World Development, 15(1), pp. 145-159.

Kwon, S.A. (2008). Moving from Complaints to Action: Oppositional Consciousness and Collective Action in a Political Community. Anthropology \& Education Quarterly, 39(1), pp. 59-76. DOI:10.1111/ j.1548-1492.2008.00005.x.

Lang, S. (2013). NGO's, Civil Society and the Public Sphere, Cambridge: Cambridge University Press.

Lennox, C. (2012). Natural resource development and the rights of minorities and indigenous peoples. In B. Walker (Ed.), State of the World's Minorities and Indigenous Peoples 2012, pp. 10-21. Minority Rights Group International.

Li, T. M. (2007). Governmentality. Anthropologica, 4(92), pp .275-281.

Li, T. M. (2012). The Will to Improve: Perencanaan, Kekuasaan dan Pembangunan di Indonesia. Tangerang Selatan: Marjin Kiri

McSweeney, J. (2014). The Absence of Class: Critical Development, NGOs and Misuse of Gramsci's Concept of Counter Hegemony. Progress in development Study, 14(3), pp. 275-285. DOI: 10.1177/1464993414521339

Miles, M.B., Huberman, A.M. (1992). Analisis Data Kualitatif: Buku Tentang MetodeMetode Baru. Jakarta: UI Press.

Moniaga, S. (2010). "Dari Bumi Putera Ke Masyarakat Adat: Sebuah Perjalanan Panjang dan Membingungkan", dlm: Davidson, J.S., Henley, D. \& Moniaga, S. (ed)., Adat Dalam Politik Indonesia. Jakarta: KITLV dan Yayasan Pustaka Obor Indonesia.

Morton, A.D. (2007). Unravelling Gramsci: Hegemony and Passive Revolution in the Global Political Economy. London: Pluto Press
Northcott, H.A. (2012). Realisation of the right of indigenous people to Natural Resources Under International Law Through the Emerging Right to Autonomy. The International Journal of Human Right, 16(1), pp. 73-99. DOI: $10.1080 / 13642987.2011 .611335$

Panda, B. (2007). Top Down or Bottom Up? A Study of Grassroots NGOs' Approach. Journal of Health Management, 9(2), pp. 257-237. DOI: $10.1177 / 097206340700900207$

Patria, N., Arief, A. (1999). Antonio Gramsci: Negara Dan Hegemoni. Yogyakarta: Pustaka Pelajar.

Peluso, N.L. (1995). Whose Woods are These? Counter-mapping Forest Territories in Kalimantan, Indonesia. Antipode, 27(4), pp. 383-406. DOI: 10.1111/j.1467-8330. 1995.tb00286.x

Peluso, N.L. (2006). Hutan Kaya Rakyat Melarat: Penguasaan Sumber daya dan perlawanan di Jawa. Jakarta: Konphalindo

Peluso, N.L ., $\quad$ Vandergeest, P. (2011). Political Ecologies of War and Forest: Counter Insurgencies and the Making of National Natures. Annals of the Association of American Geographers, 101(3), pp. 587607. DOI: 10.1080/00045608.2011.560064

Petras, J., Veltmeyer, H. (2002). Menelanjangi Globalisasi: Sepak Terjang Imperialisme di Abad 21. (terjemahan Agung Prihantoro), Yogyakarta: Kreasi Wacana.

Pretty, J.N. (2009). The Intersection of Biological Diversity and Cultural Diversity: Towards Integration. Conservation and Society, 7(2), pp. 100-112. DOI:10.4103/0972-4923.58642

Rangi, F. (2013). Yang Tersingkir Dan Yang Eksklusif: Orang Dodolo, REDD+ dan Aktivisme Masyarakat Adat di Sulawesi Tengah. Tesis. Yogyakarta: Universitas Gadjah Mada.

Ribot, J. C., Peluso, N. L. (2003). A Theory of Access. Rural Sociology, 68(2), pp. 153-181. DOI:10.1111/j.1549-0831.2003.tb00133.x.

Sangadji, A. (2002). Politik konservasi orang Katu di Behoa Kakau. KPSHK.

Sangadji, A. (2002). Politik Konservasi: Orang Katu di Behoa Kakau. Bogor: KpSHK.

Scott, J. C. (1985). Weapons of the weak: Everyday forms of peasant resistance. Yale University Press. 
Mohamad Bustam - Peran Lembaga Swadaya Masyarakat dalam Penetapan Taman Nasional Lore Lindu: Studi Yayasan Tanah Merdeka dalam Memperjuangkan Hak Masyarakat Katu

Simon, R. (1999). Gagasan-Gagasan Politik Gramsci. Yogyakarta: Insist Press dan Pustaka Pelajar.

Sugiono, M. (1999). Kritik Antonio Gramsci Terhadap Pembangunan Dunia Ketiga. Yogyakarta: Pustaka Pelajar.

Vandergeest, P., Peluso. N.L. (1995). Territorialization and State Power in
Thailand. Theory and Society, 24(3), pp. 384-426. DOI: $10.1007 /$ BF009933

Yayasan Tanah Merdeka. (2011). Kesepakatan To'i Katu (2011- 2015): Perencanaan Pembangunan Sumber daya Alam Desa Katu, Kecamatan Lore Tengah, Kabupaten Poso, Provinsi Sulawesi Tengah, 12-13 Februari 2011 